\title{
1 Characterization and fate of EfOM during ozonation applied for effective
}

2 abatement of recalcitrant micropollutants

3

4 Alberto Cruz-Alcalde*, Santiago Esplugas, Carme Sans

5

6 Department of Chemical Engineering and Analytical Chemistry, Faculty of Chemistry,

7 Universitat de Barcelona, C/Martí i Franqués 1, 08028 Barcelona, Spain. Tel:

$8 \quad+34934029789 ;$ fax: +34934021291

9

$10 *$ Corresponding Author: alberto.cruz@ub.edu

12 ABSTRACT

14 Alterations occurring in the effluent organic matter (EfOM) during ozonation could be 15 detrimental depending on the final application of the treated effluent. In this work, the 16 fate of EfOM in different ozonized wastewaters was assessed through the monitoring of 17 general water quality parameters and organic fractions determined through size-exclusion 18 chromatography combined with organic carbon detection (SEC-OCD) analysis. These 19 different components of EfOM were distinguished based on relative molecular weights 20 and assigned to fractions named as biopolymers, humic substances, building blocks and

21 low molecular weight neutrals and acids. The significant abatement (60-90\%) of an 22 ozone-refractory micropollutant (MP) was employed as reference to simulate potential 23 scenarios in which also the presence of these species is wanted to be attenuated.

24 Ultraviolet absorbance at $254 \mathrm{~nm}\left(\mathrm{UVA}_{254}\right)$ and chemical oxygen demand (COD) 25 reductions ranged from 40 to $80 \%$ and from 10 to $45 \%$, respectively, for ozone doses 
between 0.6 and $1.0 \mathrm{mM}$, depending on the organic matter content (both dissolved and suspended) and alkalinity of the effluents. Dissolved organic carbon (DOC) analysis showed 21-27\% reductions in Membrane bioreactor (MBR) effluents, whereas for conventional activated sludge (CAS) samples this value increased (6-35\%) during the oxidative treatment. This was attributed to the continuous solubilization of humic

31 substances, according to SEC-OCD results. Moreover, accumulation of lower molecular weight fractions such as building blocks or acids was observed in all the tested effluents, and attributed to the breakdown of largest EfOM fractions, mainly humic substances. Relationships proposed in this work between humic substances evolution, water quality $\left(\mathrm{UVA}_{254}\right)$ and process parameters (immediate ozone demand (IOD), IOD-normalized hydroxyl radical exposure $\left(\int[\bullet \mathrm{OH}] \mathrm{d} t / \mathrm{IOD}\right)$ and transferred ozone dose (TOD)) might be useful for EfOM variations estimations along ozonation.

\section{KEYWORDS}

41 Wastewater ozonation, micropollutants oxidation, EfOM fractions, SEC-OCD, humic substances

\section{Introduction}

In a time in which water scarcity increasingly constitutes one of the most serious threats

47 for human and environmental safety, enhanced wastewater treatment and reclamation consolidates as the strategy to follow if sustainability regarding this vital resource is wanted to be preserved [1-3]. Advanced treatment of effluents released into freshwater bodies minimizes the negative impacts (i.e., pollution of the receiving aqueous 
compartments) derived from this practice. On the other hand, reclaimed wastewater can

52 be employed for a variety of non-potable uses, including agricultural and municipal irrigation, environmental applications, recreational activities or industrial processes $[3,4]$. By means of these practices, significant volumes of freshwater are saved. However, the use of this alternative water source in applications implying further human or animal exposure is limited by the presence -among others- of organic micropollutants (MPs) which, although in general not regulated, pose potential risks for living species [1]. Considering this particular issue, ozonation and activated carbon are nowadays one of the most recognized advanced treatment technologies for enhanced wastewater treatment and

60 reclamation purposes [5-11].

61

62 So far, most studies dealing with ozonation of wastewater effluents mainly focus on the fate of ozone-sensitive micropollutants and harmful oxidation byproducts - such as bromate [12-14] - under such operational conditions (i.e., low ozone doses). Higher oxidant doses such as those required for ozone-resistant MPs abatement are in general not considered in full-scale ozonation steps, although several organic compounds typically

67 present in wastewater effluents are recalcitrant to ozone and present toxic properties which should encourage their effective abatement. On their part, changes in effluent organic matter (EfOM) are traditionally set aside or studied, at most, through the variation of general related parameters such as total and dissolved organic carbon (TOC and DOC, respectively), chemical oxygen demand (COD) or ultraviolet absorbance at $254 \mathrm{~nm}$

72 (UVA 254$)$ [15-20]. There is still, however, a lack of knowledge regarding the fate of the different organic fractions during municipal wastewater ozonation. Deeper information can be obtained by means of size-exclusion chromatography in combination with organic carbon detection, SEC-OCD [21], which is able to separate and quantify different EfOM 
76 fractions according to their relative molecular weights and additional measurements such

77 as $\mathrm{UVA}_{254}$ or organic nitrogen content.

There are several publications in literature describing the impact of wastewater effluent ozonation on EfOM fractions [22-31]. However, in some of these works the employed ozone doses were either not properly quantified [22,23] or too high to be considered for practical applications [24]. Moreover, changes in EfOM fractions are often available in a very qualitatively way [25-27], or expressed as variations in the average molecular size but not quantified in terms of organic carbon concentrations [28,29]. In other few works, changes in EfOM fractions were not related to or discussed together with micropollutants oxidation or the reduction of any other general parameters typically monitored in wastewater treatment $[30,31]$. None of these studies discuss the fate of EfOM for various wastewater sources presenting different water qualities.

EfOM contained in reclaimed wastewater treated by ozonation can cause some technical and environmental problems if further treatments are planned next. For instance, residual organic matter (OM) could contribute to the formation of harmful disinfection byproducts in a subsequent disinfection step, or be partly responsible for membrane fouling in a filtration unit $[32,33]$. Also, EfOM can compete with target pollutants for adsorption sites in activated carbon systems or avoid the separation of these chemicals from the water matrix if these are bound to the organic matter surface $[32,33]$. Moreover, since prior to

97 be used this water need to be redirected to its final destination, EfOM - especially its lower molecular weight fractions - can be a perfect substrate for bacterial growth in

99 distribution systems, or cause eutrophication in receiving water compartments if the final

100 use is related to surface or groundwater recharge [32]. 
102 This work aimed to contribute to the - still - scarce knowledge regarding the variation of

103 EfOM fractions during ozonation of wastewater effluents. Concretely, the objective of

104 the study was to assess changes taking place when ozone doses required for the effective

105 abatement of micropollutants are applied, including the elimination of ozone-resistant

106 species. Thus, a potentially realistic scenario was explored in this study. To do so,

107 ozonation experiments in semi-continuous mode where performed for six different

108 wastewater effluents presenting a wide range of water qualities and spiked with an ozone-

109 resistant organic micropollutant as internal reference. The evolution of distinguishable

110 dissolved EfOM fractions was then followed by means of the SEC-OCD technique,

111 together with variations observed for other parameters typically discussed in practice,

112 such as $\mathrm{UVA}_{254}, \mathrm{COD}$ and DOC. Finally, some relationships between EfOM changes and

113 some effluent quality and ozonation parameters were discussed.

114

\section{2. Materials and methods}

\section{2.1. Wastewater effluents}

119 Six different wastewater effluents coming from five wastewater treatment plants

120 (WWTPs) in the province of Barcelona (Spain) were employed in this work. All of them

121 treat municipal wastewater. Technical details of WWTPs from which they were collected

122 are gathered in Table 1. All effluents samples were filtered through $25 \mu \mathrm{m}$ filter paper to

123 remove coarse particles not belonging to the effluent (e.g., dragged from the sample

124 collection system) and avoid technical problems with the equipment used during 
125 ozonation experiments (e.g., ozone sensor). All the effluent samples were kept at $4{ }^{\circ} \mathrm{C}$

126 until they were used.

127

128 Table 1. List of wastewater effluent samples used in this work and technical details of WWTPs from which

129 they were collected. (PC: primary clarification; MBR: membrane bioreactor; UF: ultrafiltration membrane;

130 NR: nutrient removal; CAS: conventional activated sludge; IFAS: Integrated fixed-film activated sludge;

131 SC: secondary clarification).

\begin{tabular}{ccccc}
\hline Sample & WWTP & $\begin{array}{c}\text { Population } \\
\text { equivalent } \\
\text { ID }\end{array}$ & $\begin{array}{c}\text { Design flow } \\
{[\mathbf{P E}]}\end{array}$ & $\begin{array}{c}\text { Type of treatment } \\
{\left[\mathbf{m}^{\mathbf{3}} \mathbf{d}^{-1}\right]}\end{array}$ \\
\hline M1 & Vacarisses & 5280 & 1320 & PC + MBR (UF) with NR \\
M2 & Vallvidrera & 5500 & 1100 & PC + MBR (UF) with NR \\
M3 & Gavà & 192000 & 32000 & PC + MBR (UF) with NR \\
C1 & El Prat & 2275000 & 420000 & PC + CAS with NR + SC \\
C2 & Gavà & 192000 & 32000 & PC + IFAS with NR + SC \\
C3 & La Llagosta & 358333 & 43000 & PC + CAS + SC \\
\hline
\end{tabular}

132

133

\subsection{Ozonation experiments}

135 Wastewater ozonation experiments were performed in a $750 \mathrm{~mL}$ semi-batch reactor, at a

136 temperature of $20^{\circ} \mathrm{C}$ and without $\mathrm{pH}$ adjustment. Ozone was generated by using a 301.19

137 lab ozonizer (Sander, Germany) and introduced into the reactor through a porous diffuser.

138 A mechanical stirrer was used to provide a proper contact between liquid and gas phases.

139 The gas flow rate and the ozone inlet concentration were maintained at $0.1 \mathrm{~L} \mathrm{~min}^{-1}$ and

$1400.63 \mathrm{mmol} \mathrm{L} \mathrm{L}^{-1}$, respectively. The transferred ozone dose (TOD), which represents the 
141 ozone consumption, was determined through continuous evaluation of the $\mathrm{O}_{3}$ mass

142 balance in the gas phase [34]. Inlet and outlet ozone concentrations were measured by

143 two BMT 964 ozone analyzers (BMT Messtechnik, Germany). The residual

144 concentration of ozone in the aqueous phase was monitored by means of a Q45H/64

145 dissolved $\mathrm{O}_{3}$ sensor (Analytical Technology, USA).

146

147 Each wastewater effluent was spiked with $0.45 \mu \mathrm{M}$ of the pesticide acetamiprid (ACMP),

148 here employed as reference micropollutant because of its resistance to molecular ozone

149 attack during ozonation, and then ozonized for 30 min under the mentioned operational

150 conditions. Samples were withdrawn at known time intervals and kept at room conditions

151 until complete consumption of dissolved ozone was achieved. Then, analyses for ACMP,

152 typical physicochemical parameters (namely $\mathrm{UVA}_{254}, \mathrm{DOC}$ and COD) and EfOM

153 fractions were conducted.

154

155 Immediate ozone demand (IOD) of each wastewater sample was estimated in this work

156 as the minimum TOD required to detect dissolved ozone in the reaction medium [38].

157 The initial hydroxyl radical $(\bullet \mathrm{OH})$ consumption rates, which provide information about

158 the amount of $\bullet \mathrm{OH}$ available in the reaction medium for micropollutant oxidation [39],

159 were here estimated considering the sum of contributions by dissolved EfOM and

160 alkalinity. For EfOM contribution, a mean rate constant value between dissolved EfOM

161 and $\cdot \mathrm{OH}$ of $2.1 \cdot 10^{5}\left(\mathrm{mg} \mathrm{C} \mathrm{L}^{-1} \mathrm{~s}^{-1}\right.$ was used according to the work by Lee et al. [10],

162 together with the DOC values determined for each effluent sample (see Table 3).

163 Consumption rate due to alkalinity was calculated according to the known rate constant

164 of bicarbonate ion reaction with $\cdot \mathrm{OH}\left(8.5 \cdot 10^{6} \mathrm{M}^{-1} \mathrm{~s}^{-1}[40]\right)$ and the IC values determined 
165 for each effluent sample (see Table 3). Thus, calculations were performed according to

166 the expression $\cdot \mathrm{OH}_{\text {scavenging rate }}=2.1 \cdot 10^{5} \cdot \mathrm{DOC}+8.5 \cdot 10^{6} \cdot \mathrm{IC}$.

167

168

\subsection{Analytical methods}

169

170 ACMP concentration was determined through HPLC-UV. Samples were previously

171 filtered through $0.45 \mu \mathrm{m}$ polytetrafluoroethylene (PTFE) filters. The mobile phase 172 consisted of 70:30 volumetric mixtures of acetonitrile and ultrapure water at $\mathrm{pH} 3$

173 (achieved by addition of $\mathrm{H}_{3} \mathrm{PO}_{4}$ ). Separation was achieved by means of a $25 \mathrm{x} 0.46 \mathrm{~cm}$ ( 5

$174 \mu \mathrm{m}$ size packing) Sea18 column (Teknokroma, Spain). The flow rate and injection

175 volume were set at $1 \mathrm{~mL} \mathrm{m^{-1 }}$ and $100 \mu \mathrm{L}$, respectively. Detection was performed at 254

$176 \mathrm{~nm}$. UV absorbance at $254 \mathrm{~nm}$ was measured by means of a DR6000 UV Vis

177 spectrophotometer (Hach, USA) employing a quartz cuvette (path length: $1 \mathrm{~cm}$ ). TOC,

178 DOC and inorganic carbon (IC) were measured by means of a Shimadzu TOC-VCSN

179 analyzer. COD was determined according to Standard Methods procedure 5220D [36].

180 Nitrite $\left(\mathrm{NO}_{2}^{-}\right)$concentration was determined by means of ion-exchange chromatography

181 with UV detection. For DOC, IC, $\mathrm{UVA}_{254}$ and nitrite analyses, samples were previously

182 filtered through $0.45 \mu \mathrm{m}$ PTFE filters. In order to characterize EfOM fractions after

183 applying particular ozone doses, the SEC-OCD technique from DOC-Labor was

184 employed. Detailed information regarding this technique can be found elsewhere [21,37].

185 In summary, samples were previously filtered through $0.45 \mu \mathrm{m}$ PTFE filters. The mobile

186 phase was a phosphate buffer $(0.01 \mathrm{M}, \mathrm{pH}$ 7) containing $0.1 \mathrm{M}$ of $\mathrm{NaCl}$. Separation of

187 EfOM fractions by molecular weight was achieved by using a $25 \times 2.2 \mathrm{~cm}$ column filled

188 with HW-50 resin purchased from Sigma-Aldrich (Germany). Operation flow-rate and

189 injection volume were $1 \mathrm{~mL} \mathrm{~min}^{-1}$ and $1 \mathrm{~mL}$, respectively. As mentioned, the SEC-OCD 
190 procedure consists of size exclusion chromatography (SEC) followed by organic carbon

191 detection. For calibration of humic substances molecular weights, Suwannee River 192 standard humic and fulvic acids were employed. Both were acquired from the

193 International Humic Substances Society. Based on the good agreement between the

194 chromatographic behavior of these standards and that of effluent samples, as well as to

195 additional $\mathrm{UVA}_{254}$ measurements, the name humic substances (HS) was assigned to one

196 of the observed EfOM fractions. The nominal average molecular weights of fulvic and

197 humic acid standards (711 and 1066, respectively) could be used to determine the

198 molecular weight distribution of HS. The fraction with the highest molecular size (thus,

199 eluting first and before HS) received the name biopolymers (BP). The fraction observed

200 after HS elution was named as building blocks (BB), and was related to products coming

201 from the breakdown of humic substances. The names low molecular weight acids and

202 neutrals (LMWA and LMWN, respectively) were assigned to those fractions eluting last.

203 The slightly more hydrophobic character of LMWN compared to LMWA allowed

204 distinction between both fractions. A summary of the different fraction assignments can

205 be found in Table 2. It has to be noted that fraction assignments in this work were made

206 using the same fraction names firstly proposed by Huber and coworkers for

207 characterization of organic matter in natural waters [21,37], and then adopted by other

208 researchers for description of other types of water samples, including wastewater

209 effluents [39].

210

211 Table 2. Properties of dissolved EfOM fractions distinguished in SEC-OCD analyses.

\begin{tabular}{ccc}
\hline Dissolved EfOM & Molecular & Description \\
fraction assignment & weight & \\
\hline
\end{tabular}




\begin{tabular}{ccc}
\hline $\begin{array}{c}\text { Biopolymers (BP) } \\
\text { Humic substances }\end{array}$ & $\begin{array}{r}\text { Associated to amino sugars, polypeptides and } \\
\text { proteins. Do not absorb UV radiation. }\end{array}$ \\
(HS) & $\begin{array}{r}\text { Mix of hydrophobic humic substances and } \\
\text { humic/fulvic acids, in varying concentrations }\end{array}$ \\
Building blocks (BB) & $300-450$ & $\begin{array}{c}\text { Degradation intermediates of humic substances } \\
\text { Low molecular weight }\end{array}$ \\
neutrals (LMWN) & $<300$ & Short chain, non-acidic degradation products: \\
Low molecular weight & $<300$ & alcohols, aldehydes, ketones... \\
acids (LMWA) & & \\
\hline
\end{tabular}

212

213 3. Results and discussion

214

215 3.1. Effluent characteristics

216

217 The main physicochemical characteristics of all effluent samples are gathered in Table 3.

218 Differences observed in the main quality parameters of tested effluents were attributed to

219 particular WWTPs technologies and operational conditions, especially those regarding

220 biological processes and subsequent separation steps. They covered a relatively broad

221 range of effluent qualities and therefore represented the diverse range of wastewaters that

222 currently can be found in practice.

223

224 Table 3. Effluent quality parameters. M and C stands for MBR and CAS effluents, respectively. All

225 measurements were performed per triplicate $(n=3)$. Discrepancies between replicates were in all cases lower

226 than 5\%.

\begin{tabular}{|c|c|c|c|c|c|c|c|c|c|}
\hline $\begin{array}{c}\text { Sample } \\
\text { ID }\end{array}$ & $\begin{array}{l}\text { WWTP } \\
\text { location }\end{array}$ & pH & $\begin{array}{c}\mathbf{U V A}_{254}{ }^{*} \\
{\left[\mathrm{~m}^{-1}\right]}\end{array}$ & $\begin{array}{c}\text { TOC } \\
{\left[\mathrm{mg} \mathrm{C} \mathrm{L}^{-1}\right]}\end{array}$ & $\begin{array}{c}\mathrm{DOC}^{*} \\
{\left[\mathrm{mg} \mathrm{C} \mathrm{L}^{-1}\right]}\end{array}$ & $\begin{array}{c}\text { COD } \\
{\left[\mathrm{mg} \mathrm{O}_{2} \mathrm{~L}^{-1}\right]}\end{array}$ & $\begin{array}{c}\text { Turbidity } \\
\text { [NTU] }\end{array}$ & $\begin{array}{c}\mathrm{IC}^{*} \\
{\left[\mathrm{mg} \mathrm{C} \mathrm{L}^{-1}\right]}\end{array}$ & $\begin{array}{c}\mathrm{NO}_{2}^{-*} \\
{\left[\mathrm{mg} \mathrm{N} \mathrm{L}^{-1}\right]}\end{array}$ \\
\hline
\end{tabular}




\begin{tabular}{cccccccccc}
\hline M1 & Vacarisses & 7.9 & 17.9 & 6.7 & 6.6 & 14.9 & 0.6 & 87.4 & 0.9 \\
M2 & Vallvidrera & 7.4 & 16.3 & 10.5 & 10.3 & 20.7 & 0.9 & 42.7 & $<0.1$ \\
M3 & Gavà & 7.7 & 14.9 & 12.4 & 12.1 & 16.6 & 0.3 & 53.0 & 0.1 \\
C1 & El Prat & 7.5 & 22.9 & 14.0 & 13.6 & 29.7 & 1.1 & 63.6 & 0.1 \\
C2 & Gavà & 7.8 & 67.2 & 42.1 & 27.6 & 93.5 & 28.6 & 114.7 & 0.1 \\
C3 & La Llagosta & 7.7 & 66.4 & 25.6 & 21.3 & 53.0 & 20.1 & 98.3 & $<0.1$ \\
\hline
\end{tabular}

* Samples were filtered through $0.45 \mu \mathrm{m}$ PTFE filters for the measurement of these parameters.

228

229 3.2. Ozone demand, radical scavenging and removal of the reference compound ACMP

230

231 Estimated values of IOD and $\bullet \mathrm{OH}$ consumption rates are presented in Table 4.

232

233 Table 4. Estimated IOD and $\bullet \mathrm{OH}$ consumption rates of tested effluent samples. EfOM contributions in 234 samples C2 and C3 may have been underestimated, as only dissolved EfOM was taken into account.

\begin{tabular}{ccccccc}
\hline Effluent sample ID & M1 & M2 & M3 & C1 & C2 & C3 \\
\hline IOD [mmol $\left.\mathbf{O}_{\mathbf{3}} \mathbf{L}^{-1}\right]$ & 0.29 & 0.19 & 0.23 & 0.3 & 0.6 & 0.4 \\
$\bullet$ OH consumption rate $\left[\mathbf{s}^{-1}\right]$ & $2.0 \cdot 10^{5}$ & $2.5 \cdot 10^{5}$ & $2.9 \cdot 10^{5}$ & $3.3 \cdot 10^{5}$ & $6.6 \cdot 10^{5}$ & $5.2 \cdot 10^{5}$ \\
\hline
\end{tabular}

235

236 Although relatively low $\mathrm{O}_{3}$ doses (e.g., $0.1-0.3 \mathrm{mmol} \mathrm{L}^{-1}$ or 5-15 $\mathrm{mg} \mathrm{L}^{-1}$ ) should be

237 enough to meet the removal of organic compounds with medium or high reactivity to 238 ozone $[10,11,14,41]$, this criteria could get gradually stricter as is likely to occur in view 239 of the increasing water scarcity and concern on micropollutants presence in water 240 resources. Then, the abatement of even those MPs recalcitrant to ozone may be also 241 required in a near future. In this study, we selected ACMP as reference compound on the 242 basis of this hypothesis. ACMP reacts very slowly with ozone [35], and therefore only 
243 hydroxyl radicals generated through $\mathrm{O}_{3}$ decay contribute to its degradation during

244 ozonation. If ozone-resistant MPs such as this pesticide are significantly removed from

245 wastewater effluents, a higher abatement of any other compound with higher sensitivity

246 towards ozone attack would be guaranteed. Furthermore, $\mathrm{O}_{3}$ doses necessary for

247 disinfection purposes are generally lower than that for micropollutant oxidation $[9,42]$.

249 Measurements of the reference compound ACMP ([ACMP $\left.]_{0}: 0.45 \mu \mathrm{M}\right)$ at regular 250 reaction times allowed the obtaining of the degradation profiles presented in Fig. 1. Ozone 251 doses required to reach $80 \%$ abatement of ACMP differed significantly between samples.

252 These were approximately between 0.4 and $0.8 \mathrm{mM}\left(\sim 19-38 \mathrm{mg} \mathrm{L}^{-1}\right)$ for effluents M1$253 \mathrm{M} 3$ and $\mathrm{C} 1$, whereas for effluents $\mathrm{C} 2$ and $\mathrm{C} 3$ such doses were about $1 \mathrm{mM}\left(48 \mathrm{mg} \mathrm{L}^{-1}\right)$ or 254 even higher. For an abatement level of 50\%, doses between 0.3 and $0.5 \mathrm{mM}(14-24 \mathrm{mg}$ $255 \mathrm{~L}^{-1}$ ) would instead be required for the less polluted effluents and between 0.6 and $0.8 \mathrm{Mm}$ $256 \quad\left(29-38 \mathrm{mg} \mathrm{L}^{-1}\right)$ for samples $\mathrm{C} 2$ and $\mathrm{C} 3$.

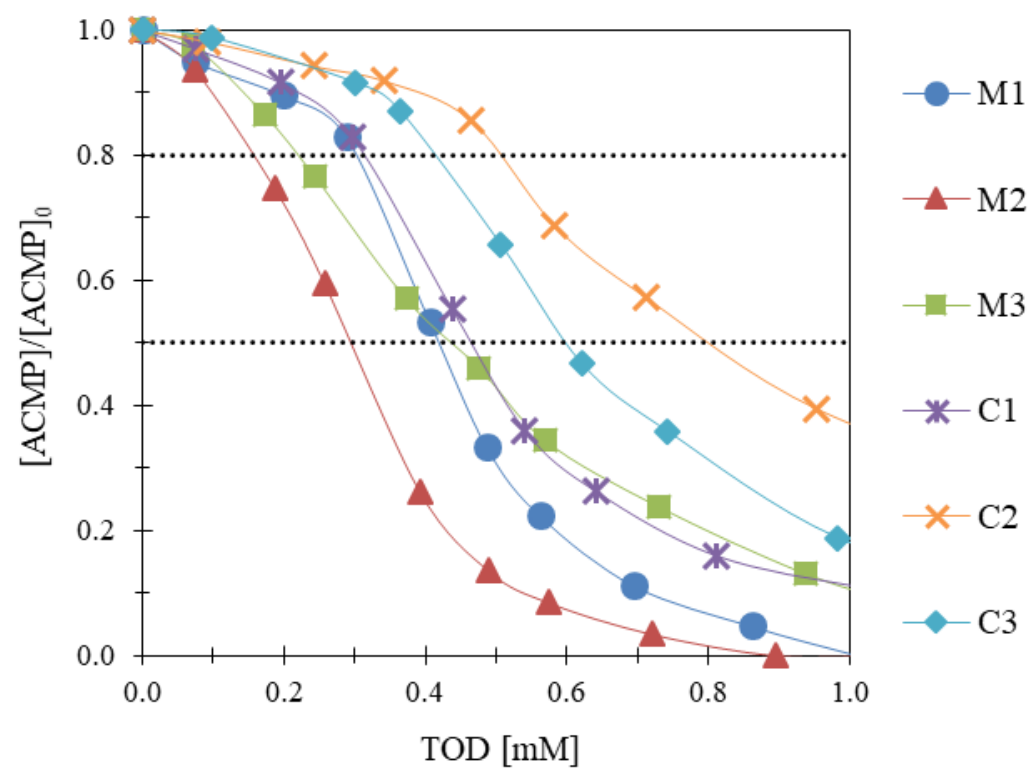

Figure 1. Abatement of the reference compound ACMP during semi-batch ozonation experiments with 260 different wastewater effluent samples. 
262 The feasibility of ozonation steps implementation for MPs abatement (including ozone263 resistant compounds) should be individually assessed for each wastewater source by 264 means of more comprehensive procedures [43], especially for those effluents presenting 265 a higher $\mathrm{O}_{3}$ demand and $\bullet \mathrm{OH}$ scavenging rate (e.g., $\mathrm{C} 2$ and $\mathrm{C} 3$ ). In any case, in this study 266 we considered maximum ozone doses of about $1 \mathrm{mM}$ as potentially practical for ozone 267 applications to enhanced wastewater treatment and reclamation goals, and explored the 268 fate of EfOM when subjected to these treatment conditions.

\subsection{Changes of general EfOM descriptors $\left(U V A_{254}, C O D\right.$ and DOC) during ozonation}

272 Changes in UV absorbance at $254 \mathrm{~nm}\left(\mathrm{UVA}_{254}\right)$ during ozonation experiments are shown in Fig. 2. Ozone typically reacts with electron-rich moieties of EfOM [39], resulting this in a sustained decrease of the wastewater UV absorption along the process. Differences observed between effluents regarding $\mathrm{UVA}_{254}$ decrease can be related to their respective water characteristics, which led to different availabilities of oxidants in the reaction medium (see estimated IOD and $\bullet \mathrm{OH}$ consumption rate values in Table 4 ). Thus, for $\mathrm{C} 2$ and $\mathrm{C} 3$ effluents, both containing important amounts of $\mathrm{O}_{3}$-consuming [20] particulate and colloidal matter (see the difference between TOC and DOC values as well as turbidity, Table 3) and alkalinity (IC), the $\mathrm{UVA}_{254}$ decrease at $30 \mathrm{~min}$ (TOD: 0.9-1.0 mM)

281 ranged between 40 and 50\%, whereas for MBR effluents (M1-M3) this value was 282 determined to be considerably higher (70-80\%) for a lower ozone consumption. In the 283 particular case of $\mathrm{C} 1$, its lower content in solid and colloidal matter (difference between 284 TOC and DOC values: $0.4 \mathrm{mg} \mathrm{C} \mathrm{L}^{-1}$; turbidity: $\left.1.1 \mathrm{NTU}\right)$ compared with $\mathrm{C} 2$ and C3 285 allowed a larger aromaticity reduction, more similar to that accounted for membrane 
286 bioreactor effluents. Other organic matter descriptors such as COD, DOC, TOC

287 (addressed in the following paragraphs) and turbidity varied along the oxidative treatment

288 displaying a similar dependence with effluent characteristics. For instance, turbidity

289 measurements at the end of treatment (i.e., after 30 min of ozonation, which corresponded

290 to the highest applied ozone dose), reductions of $70-80 \%$ for effluents M1-M3, 60\% for

$291 \mathrm{C} 1$ and about 30-40\% in the case of samples C2 and C3 were registered.

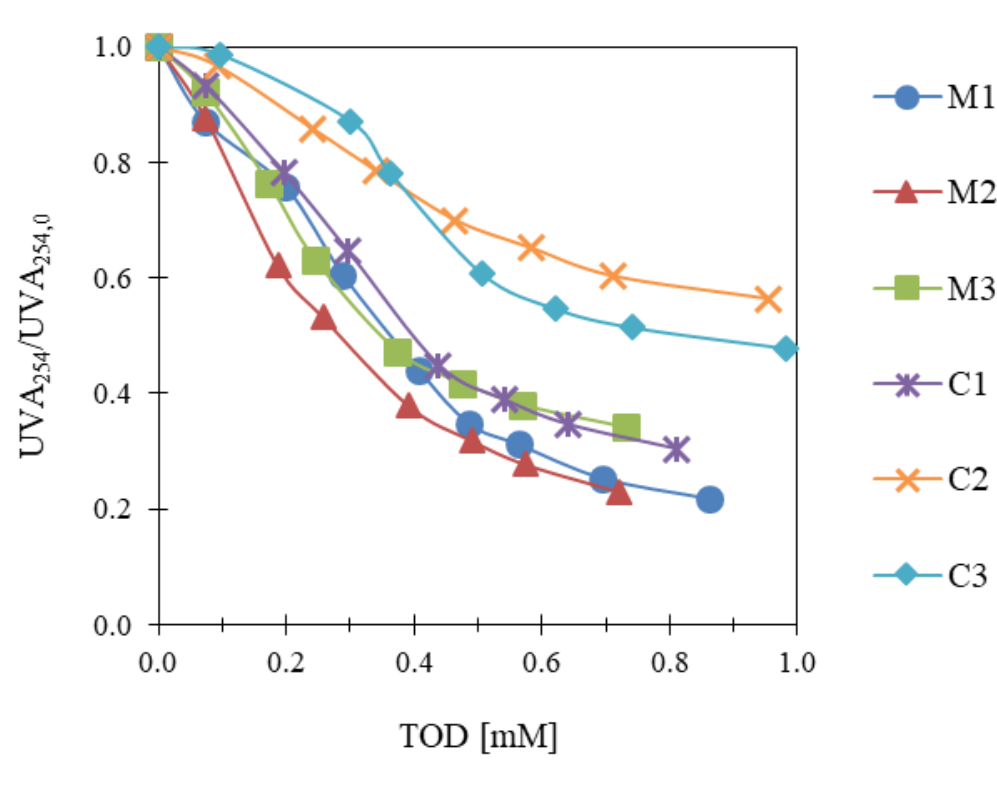

294 Figure 2. UV absorbance (at $254 \mathrm{~nm}$ ) evolution during ozonation of wastewater effluents.

296 Fig. 3 shows the COD/COD 0 profiles obtained for each water source, as a function of the

297 TOD. COD removals at the end of the treatment (TOD: 0.6-1.0 mM) ranged from 10 to

$29845 \%$, depending on the tested sample. Again, clear differences were observed between

299 effluents, together with a consistent trend for this bulk parameter with respect to the

$300 \mathrm{UVA}_{254}$ evolution, previously described. According to this, for instance, the M2 effluent

$301-$ with relatively low content in organic matter and the lowest alkalinity among the studied

302 wastewaters - was the one for which the largest COD removal was observed, whereas C2

303 and C3 samples (highest content in both organic and inorganic carbon as well as in 
304 colloidal and particulate matter) exhibited the lowest - and also the slowest-reduction for 305 this parameter.

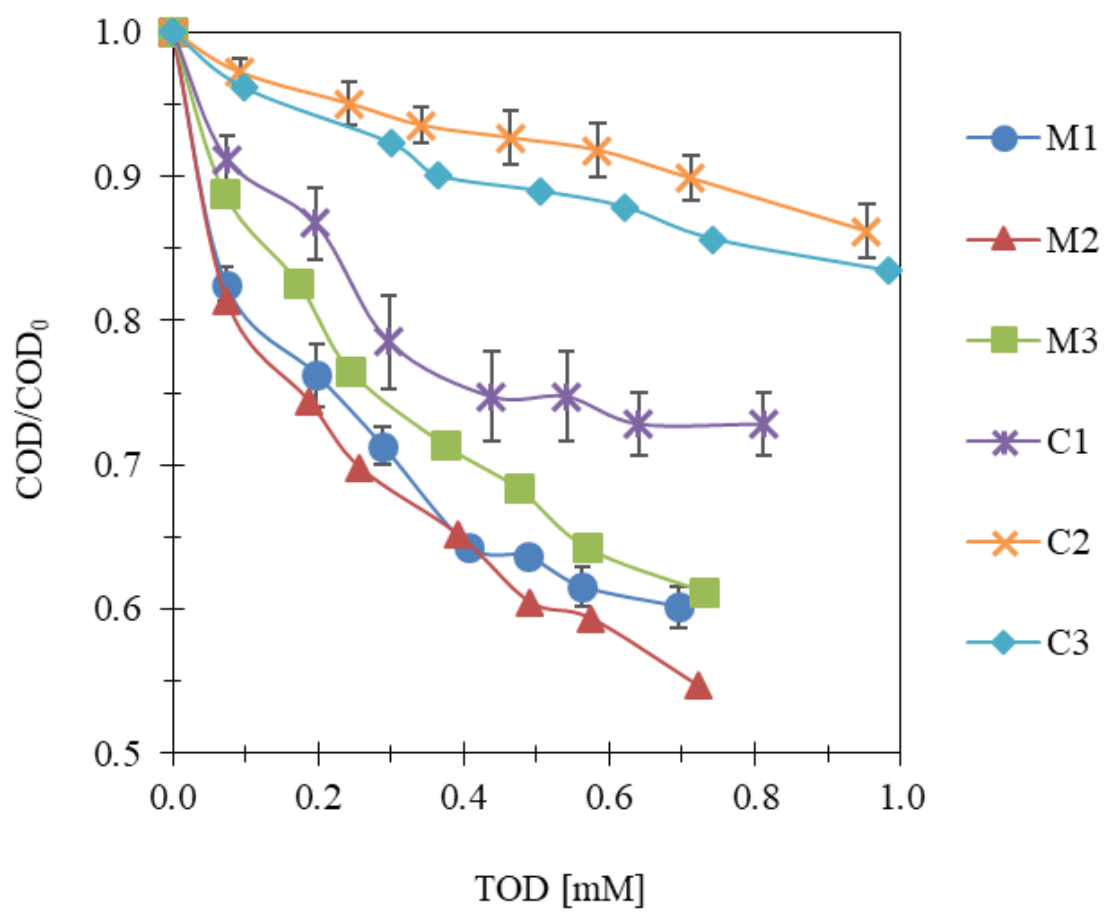

308 Figure 3. COD removal versus transferred ozone dose during semi-batch effluent ozonation experiments.

310 In general, lower overall reductions of COD (max. 45\%) in comparison to $\mathrm{UVA}_{254}$ (up to

$31180 \%$ ) were observed. It seems that the provided oxidation conditions were not strong

312 enough in order to achieve comparable levels of organic matter transformation in terms

313 aromaticity depletion and COD reduction.

315 Fig. 4 shows the percentage of DOC removal during effluent ozonation experiments, 316 determined at three different ozone doses (TOD values of 0.2-0.3, 0.3-0.5 and 0.6-1.0

$317 \mathrm{mM})$. For effluents M1, M2 and M3, all of them coming from MBR systems, the DOC 318 concentrations after 30 min of treatment (TOD: $0.6-0.7 \mathrm{mM}$ ) were reduced by $27 \%, 22 \%$ 319 and $21 \%$, respectively. TOC measurements of the same samples (data not shown) 
revealed almost identical removal values, which is logical given the fact that nearly all of

321 the organic matter was in dissolved form. In any case, organic carbon removals were in comparison lower than those reached for COD or $\mathrm{UVA}_{254}$ at the same consumed ozone doses. In wastewater ozonation, the degree of mineralization is typically low, and other

324 water quality parameters related to the organic content - such as COD and UVA 254 - are 325 in general more affected during the process. This is reasonable, as DOC concentration only is reduced when decarboxylation reactions are produced, that is, when the maximum possible level of organic matter oxidation takes place [39].

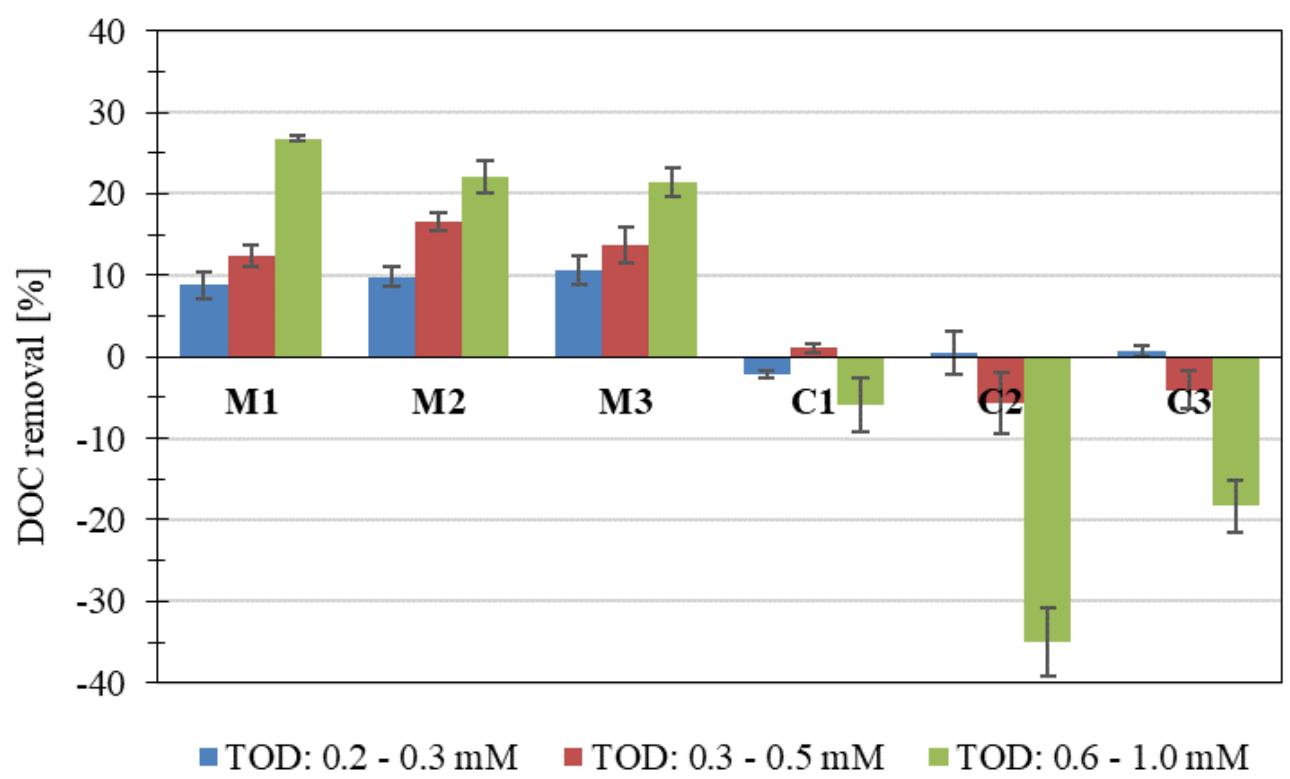

330 Figure 4. DOC concentration removal in wastewater ozonation experiments at various transferred ozone 331 doses (TOD).

333 Concerning effluents $\mathrm{C} 1, \mathrm{C} 2$ and $\mathrm{C} 3$, the observed DOC removals at the end of ozonation

334 experiments were negative in all cases. Water effluents coming from CAS systems usually contain residual amounts of suspended solids and colloids (see TOC, DOC and turbidity values of Table 3). Therefore, and in agreement with literature [44,45], it is

337 possible that part of this non-dissolved material could be solubilized upon oxidation. For 
338 the CAS effluents tested in the present study, this phenomenon was observed after

339 consumption of relatively high ozone doses (i.e., 0.7-1.0 mM), rather than at low TOD

340 values. In fact, at $\mathrm{O}_{3}$ doses between 0.2 and $0.5 \mathrm{mM}$ only small changes in the DOC

341 concentration where registered, which could be indicative of a simultaneous oxidation-

342 solubilization of, respectively, the dissolved and undissolved EfOM. An indicative of this

343 competition between degradation and solubilization may be the TOC removals measured

344 at the end of treatment, which were insignificant for samples C2 and C3 and only about $34510 \%$ in the case of $\mathrm{C} 1$.

\subsection{Evolution of EfOM fractions}

349 Figs. 5 and 6 show the evolution of (dissolved) EfOM fractions and their relative contribution to DOC during ozonation of wastewater effluents. At this point it has to be recalled that EfOM fractions referred to in the following lines are due to fraction assignments based on the chromatographic behavior of organic matter components in wastewater effluent samples, according to the methods described for SEC-OCD analyses in section 2.3. Samples coming from CAS processes presented larger percentages of biopolymers than MBR effluents (7-25\% vs $1-2 \%$, respectively), which was already expected given that ultrafiltration membranes employed in MBR units are able to retain extracellular polymeric substances (EPSs). Differences were also observed in the humic substances concentration (2697-3319 and 3335-5217 $\mu \mathrm{g} \mathrm{C} \mathrm{L}^{-1}$ for MBR and CAS, respectively) which, in agreement with previous related studies concerning membrane fouling in MBR units, suggests that a part of the largest constituents of this EfOM fraction could also be retained during the separation process $[24,46]$. 

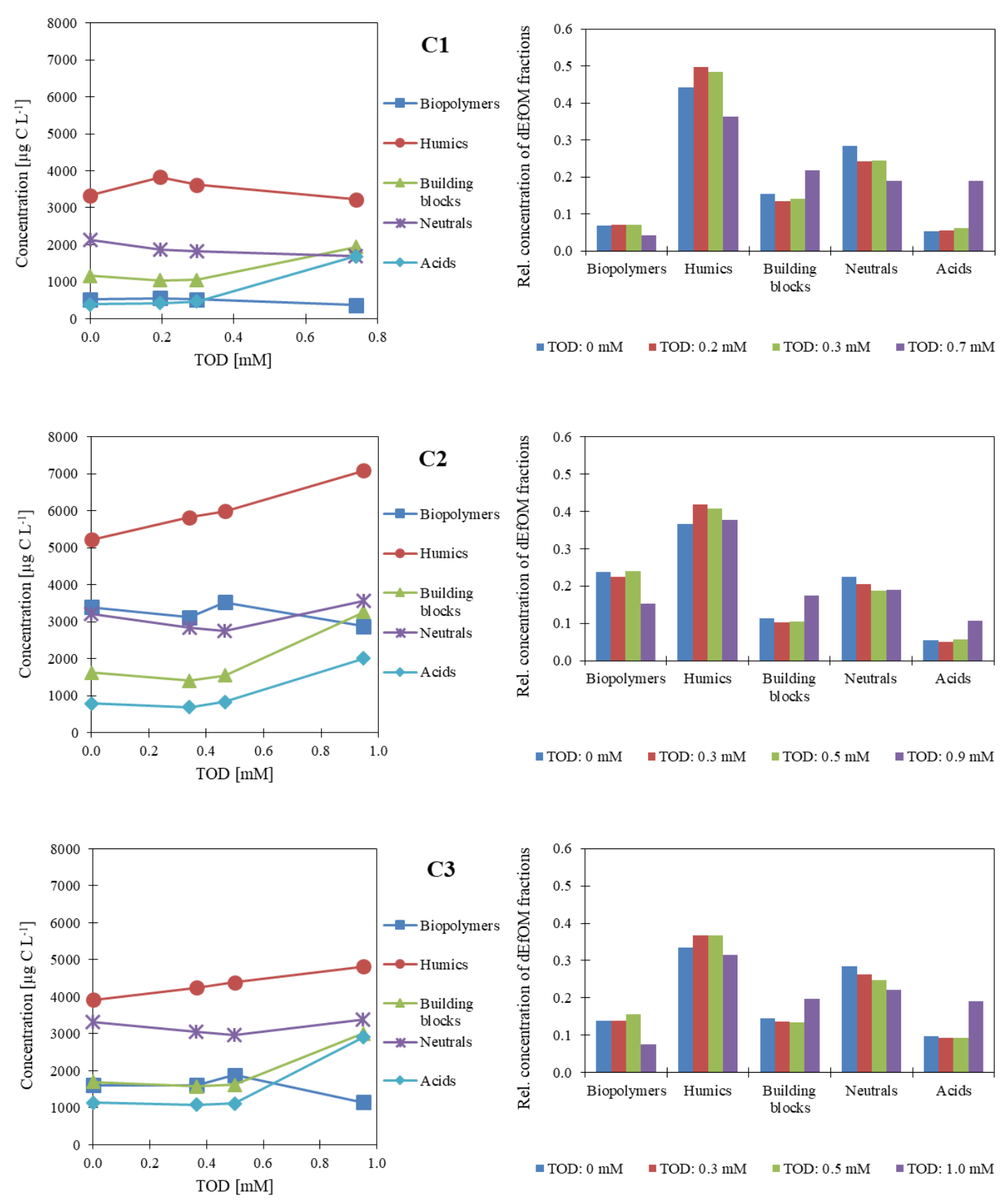

364 Figure 5. Evolution of dissolved EfOM fractions (left) and contribution to DOC (right) for ozonized CAS

365 effluents. Relative concentration of EfOM fractions in right column plots ( $y$-axis) refer to DOC of

366 considered fraction divided by total DOC.

368 Regarding CAS effluents (Fig. 5), biopolymers were not significantly removed until

369 higher doses of ozone were consumed [from 7 to $4 \%$ (C1), from 24 to $15 \%$ (C2) and from

37014 to $8 \%$ (C3) of dissolved EfOM content for $\mathrm{O}_{3}$ doses of 0.7-1.0 mM]. Especially 
371 remarkable is the case of humic substances, which noticeably increased from the

372 beginning of the treatment, especially for $\mathrm{C} 2$ and $\mathrm{C} 3$ samples. The observed accumulation

373 of humic substances during the entire $\mathrm{C} 2$ and $\mathrm{C} 3$ ozonation time, together with the fact

374 that these two waters contain the highest fraction of suspended solids among all the

375 studied effluents may be linked. Thus, the non-soluble fraction of humic substances could

376 be solubilized when oxidized [24,37]. This affirmation would be experimentally

377 supported by the DOC measurements made at different ozone doses and early seen in this

378 study, which revealed significant increases in this parameter $(35 \%$ and $18 \%$ for $\mathrm{C} 2$ and

379 C3 samples, respectively) for consumed ozone doses of 0.9-1.0 mM. Significantly higher

380 doses applied in related works for effluents containing suspended EfOM [24] could have

381 hinder a possible initial increase of this fraction followed by subsequent depletion for

382 higher oxidant dosages. This was in fact observed for sample C1, a CAS effluent

383 containing a lesser amount of suspended solids. Moreover, the continuous solubilization

384 of humic substances would provide an additional explanation to the low rates of UVA 254

385 depletion found for $\mathrm{C} 2$ and $\mathrm{C} 3$ waters. $\mathrm{BB}$ remained almost unaltered until higher ozone

386 doses were applied, which means that humic substances were not being destroyed at those

387 oxidation extents. Only at $\mathrm{O}_{3}$ doses of $0.7-1.0 \mathrm{mM}$, an enrichment in the $\mathrm{BB}$ contents

388 [from 15 to $22 \%(\mathrm{C} 1)$, from 11 to $17 \%$ (C2) and from 15 to $20 \%$ (C3)] was noticeable in

389 all EfOMs. Regarding LMWN, the concentration of this fraction increased at the end of

390 the treatment (i.e., for ozone doses of 0.7-1.0 mM) for samples $\mathrm{C} 2$ and $\mathrm{C} 3$, but only after

391 an initial - and also slight - reduction at the first stages of the process took place. On the

392 contrary, for effluent $\mathrm{C} 1$ a slightly decrease in this fraction concentration was observed

393 during the entire ozonation time. Again, differences between effluents $\mathrm{C} 2$ and $\mathrm{C} 3$, on one

394 hand, and effluent $\mathrm{C} 1$, on the other, appear to be well explained by the solubilization

395 process taking place in the first ones: the continuous introduction of humic substances to 
396 the system would hypothetically lead to an accumulation of degradation intermediates

397 (i.e., LMWN), contrarily to what typically happens in water matrices in which this re398 dissolution of OM does not significantly take place (e.g., MBR effluents and also sample

399 C1). Despite the increase in LMWN observed for C2 and C3, a gradual impoverishment 400 and accumulation of this fraction in all the tested CAS effluents was registered [overall 401 changes in EfOM composition for consumed $\mathrm{O}_{3}$ doses of $0.7-1.0 \mathrm{mM}$ : from 28 to $19 \%$ 402 (C1), from 23 to $19 \%$ (C2), from 28 to $22 \%$ (C3)]. Finally, a significant accumulation of 403 LMWA was observed for all three samples at ozone doses of $0.7-1.0 \mathrm{mM}$, leading to the 404 enrichment in this component of the corresponding EfOM compositions [from 5 to $19 \%$ 405 (C1), from 6 to $11 \%(\mathrm{C} 2)$ and from 10 to $19 \%(\mathrm{C} 3)$ ]. This evolution was predictable, as 406 carboxylic acids present low reactivity towards ozone and the contribution of hydroxyl 407 radical oxidation in complex water matrices is usually expected to be low $[39,47]$. 408

409 The evolution of EfOM fractions during ozonation of MBR effluents is shown in Fig. 6.

410 With no biopolymers nor suspended solids present in wastewater matrices, ozone 411 primarily attacked humic substances and LMWN, leading this to the gradual 412 accumulation of BB but particularly LMWA (from 4 to 18\% (M1), from 3 to 20\% (M2) 413 and from 5 to $8 \%(\mathrm{M} 3)$, for consumed ozone doses of $0.6-0.7 \mathrm{mM}$ ). The overall increase 414 of humic substances concentration observed for the M3 dissolved EfOM was the result 415 of the small changes that took place in the rest of fractions, together with a DOC reduction 416 of $c a .21 \%$ at the end of the treatment. 

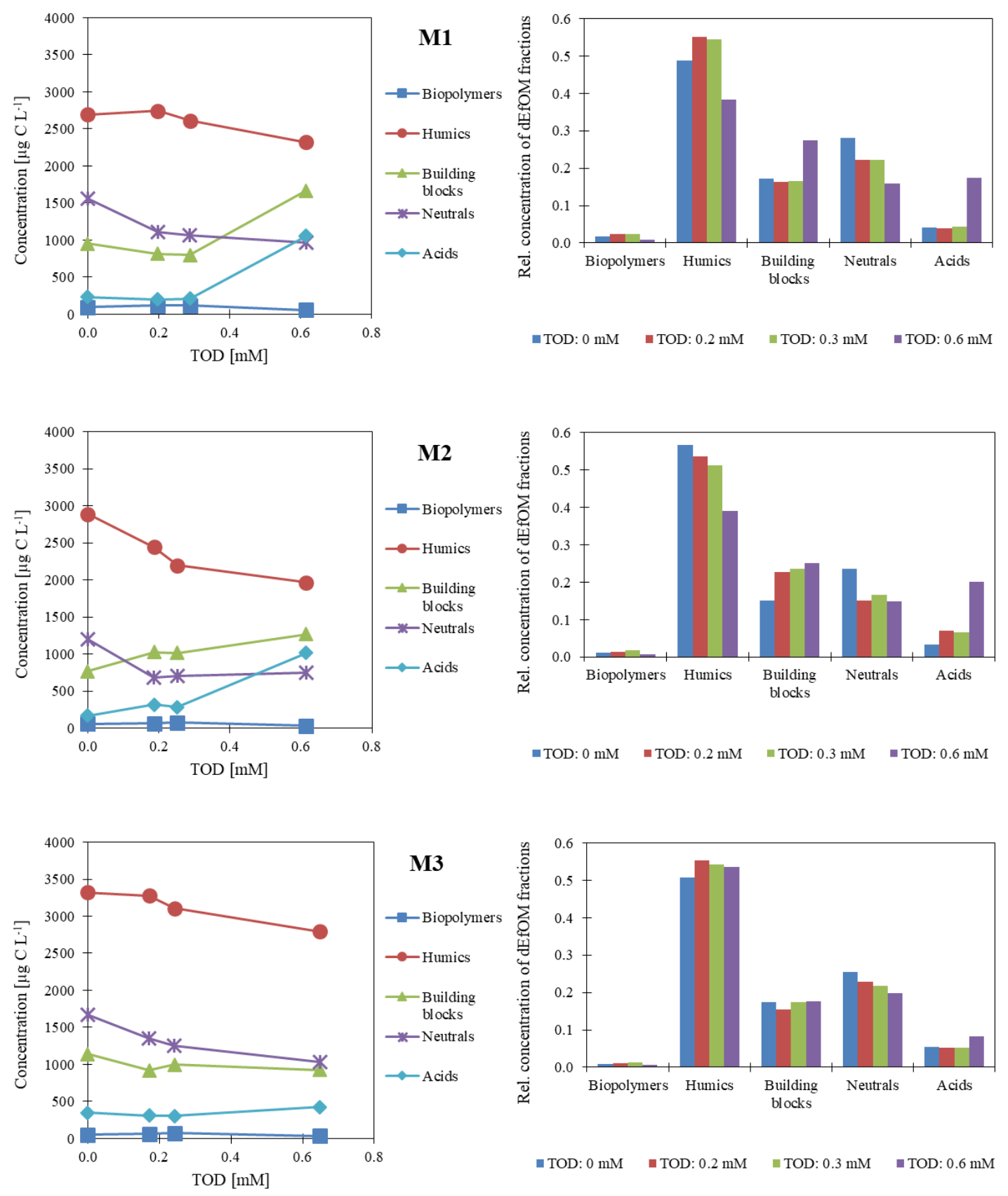

418 Figure 6. Evolution of dissolved EfOM fractions (left) and contribution to DOC (right) for ozonized MBR

419 effluents. Relative concentration of EfOM fractions in right column plots (y-axis) refer to DOC of 420 considered fraction divided by total DOC.

422 In view of the above results, it is clear that applying ozonation can change EfOM along 423 the treatment. These changes in turn, could cause negative impacts that require especial 424 mention: in first place, the cleavage of macromolecules and medium-size structures to 
yield LMWA, which are not effectively mineralized by ozone, is known for leading to

426 the enhancement of water biodegradability [20,48]. Although this could be interesting if

427 a final biological treatment step is planned (e.g., biological activated carbon), it could be

428 also detrimental if this water is discharged or directly reused instead: biodegradable

429 EfOM is a perfect substrate for bacterial growth in pipes, membranes or receiving water

430 compartments [49]. Regarding the biopolymers fraction, the observed reduction during

431 the process was in any of the cases higher than $c a .45 \%$. For CAS effluents, containing a

432 significantly higher concentration of these components, the reduction percentage was still

433 lower. This means that the greatest part of biopolymers, partly responsible for membrane

434 fouling, for instance, remained unaltered in the water matrix. With respect to particulate

435 matter solubilization during the treatment, ozonizing secondary effluents containing

436 suspended solids seems to be not recommended. Finally, increasing DOC in an already

437 treated wastewater would be in first place inefficient for obvious reasons. In addition, this

438 detrimental effect could lead to other problems such as increased generation of

439 disinfection by-products in hypothetical post-treatment.

440

\subsection{Relationship between process parameters and EfOM changes}

442

443 Although $\mathrm{UVA}_{254}$ is typically used as an estimate of the content in humic substances of 444 EfOM [19,50-53], a strict correlation between these two factors has not been observed 445 during ozonation experiments. Oxidation of humic substances initially occurs at the 446 external part of the coil formed by these molecules, which in turn prevents its inner part 447 to be destroyed by ozone and hydroxyl radicals [54]. According to the aromaticity model 448 for humic substances proposed by Del Vecchio and Blough [55], the attack on the 449 peripheral part of chemical structures of humic substances potentially leads to the 
oxidation of electron-donating or -accepting subunits responsible for charge transfer transitions. As charge transfer transitions between these structures are responsible for UV absorption, this would be enough to reduce the sample UVA 254 . Similar observations reported by studies employing chlorine as oxidizing agent [56], instead of ozone, support this hypothesis. Likewise, the observed mismatch between COD and UVA 254 reduction during ozonation experiments (see Figs. 1 and 2) could be partly related to the mentioned steric impediment caused by the spatial configuration of humic substances.
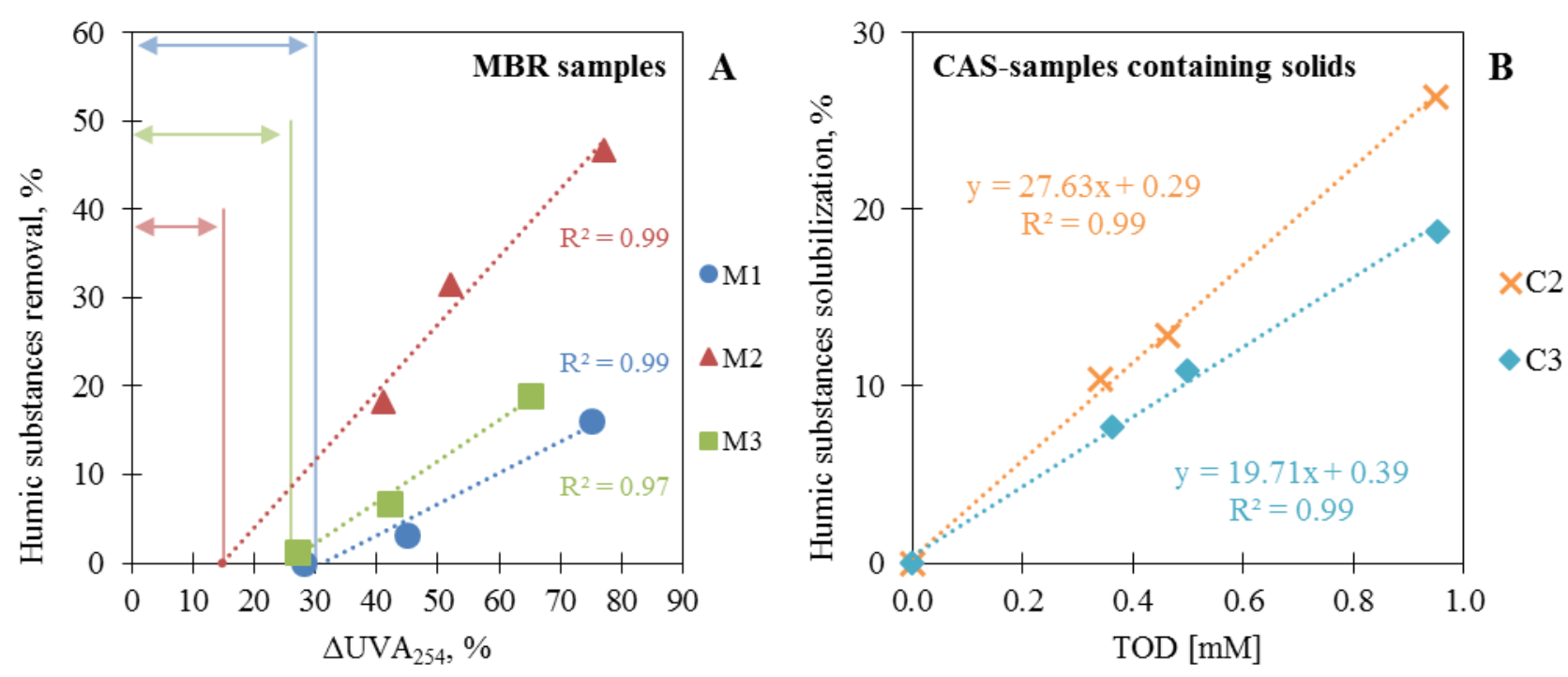

458

Figure 7. Relationship between effluent quality and process parameters with humic substances concentration in wastewater effluents ozonation. A) Humic substances removal in MBR effluent samples versus \% UVA 254 reduction; B) Humic substances solubilization versus transferred ozone dose in CAS effluent samples containing significant amounts of suspended organic matter.

464 Recent works have shown how the measurement of spectroscopic parameters (UVA and 465 fluorescence removal) could be potentially used as on-line proxies for biodegradable 466 DOC generation during ozonation and other advanced tertiary treatments $[49,57]$. This 467 biodegradable fraction of EfOM corresponds to the presence of medium-weight $\mathrm{BB}$, as well as to LMWN and LMWA. Since all these species have their origin in the cleavage 
of larger molecules of humic substances, it seems logical to put the focus on the

470 relationship between this fraction and some common effluent quality and process

471 parameters in order to anticipate potential changes during ozonation.

472

473 Fig. 7A shows a plot of the percentage of humic substances removal versus the UVA 254

474 depletion, for samples coming from MBR units. As seen, a good relationship between

475 them appears to be possible after an initial lag stage in which any abatement of humic

476 substances is observed. In other words, a degree of UV absorbance reduction is observed

477 before measuring any depletion in the concentration of humic substances. This is also

478 indicated in Fig. 7A. The magnitude of this lag can be related with the oxidizing

479 conditions of the media, since a higher availability of oxidant species favors a more severe

480 oxidation of humic substances. As known, $\mathrm{O}_{3}$ and $\bullet \mathrm{OH}$ availability during ozonation will

481 depend on the effluent characteristics, which is mainly given by the contents in organic

482 and inorganic matter that readily consume these oxidants. Interestingly, the observed

483 trend for IOD (i.e., 0.29, 0.19 and $0.23 \mathrm{mmol} \mathrm{O}_{3} \mathrm{~L}^{-1}$ for samples $\mathrm{M} 1, \mathrm{M} 2$ and $\mathrm{M} 3$,

484 respectively) agreed well with the trend observed for the lag values represented in Fig.

485 7A, which resulted to be: $\mathrm{M} 2>\mathrm{M} 3>\mathrm{M} 1$ (corresponding to $14.5,25.5$ and $31.1 \%$ of

486 UVA $_{254}$ depletion, respectively). The slope of the humic substances-UVA 254 removal

487 correlation for these waters, which would give an idea about the process kinetics, also

488 followed the same trend $(0.35,0.76$ and 0.47 for M1, M2 and M3, respectively).

489

490 Contrarily, the agreement between humic substances-UVA254 removal and IOD, on one

491 hand, and the observed lag phase and IOD, on the other, was not observed with the initial

$492 \cdot \mathrm{OH}$ consumption rate values estimated for MBR effluents. In fact, the presence of $\bullet \mathrm{OH}$

493 in the reaction medium not only depends on the consumption rate of these species by the 
water matrix but also on the capacity of consumed ozone to generate them. Therefore, a

495 better indicator of $\bullet \mathrm{OH}$ availability to react with humic substances during the first stages

496 of ozonation process should also consider ozone consumption. A good option can be the

497 use of the ratio between $\cdot \mathrm{OH}$ exposure (i.e., $\int[\cdot[\mathrm{OH}] \mathrm{d} t)$ and IOD. Hydroxyl radical

498 exposure for an ozone consumption corresponding to the IOD value could be estimated

499 in this work through ACMP degradation data presented in Fig. 1, according to the

500 calculation procedure described elsewhere [34] and based on the use of an ozone-resistant 501 compound as $\bullet \mathrm{OH}$ probe. The obtained $\int\left[\cdot[\mathrm{OH}] \mathrm{d} t / \mathrm{IOD}\right.$ values were $3.1 \cdot 10^{-7}, 7.3 \cdot 10^{-7}$ and

$5024.9 \cdot 10^{-7} \mathrm{~s}$ for samples M1, M2 and M3, respectively. As can be checked, the trend

503 followed by these values now match with the lag and slope values in Fig. 7A: the higher

504 the amount of hydroxyl radicals available per ozone dose, the stronger the oxidation

505 conditions, thus allowing a more significant (and faster) degradation of humic substances

506 by $\bullet \mathrm{OH}$ during the initial stages of ozonation.

507

508 Finally, if it was the case that ozonation was applied to a CAS effluent containing 509 significant amounts of suspended matter, the percentage of humic substances

510 solubilization in the water matrix seems to be well correlated with the transferred ozone 511 dose (TOD). This is shown in Fig. 7B: the higher the oxidation extent, the higher the 512 number of hydrophilic moieties generated in the non-soluble fractions of EfOM, which

513 can then be solubilized into the water matrix. In addition, larger concentrations of solid

514 matter, which also contribute to a higher IOD value, seem to favor faster solubilization

515 kinetics, as shown in the correlation parameters obtained in experiments with samples C2 516 and $\mathrm{C} 3$. 


\section{Conclusions}

519

520 Ozone application for the effective removal of micropollutants including ozone-resistant

521 species, which can be a potentially realistic situation in wastewater treatment in a near

522 future, from wastewater produced significant changes in EfOM concentration and quality

523 in all effluents tested. The extent of COD and $\mathrm{UVA}_{254}$ reduction agreed well with the

524 water quality of each effluent, being the most influencing factors the concentration of

525 both dissolved and particulate/colloidal matter and alkalinity. For CAS samples

526 containing relatively large amounts of suspended solids, an increase in the DOC

527 concentration was observed. This was attributed to the solubilization of non-dissolved

528 humic substances. The continuous introduction of this fraction (humic substances) in the

529 reaction medium resulted in the net accumulation of this component. Only for samples

530 coming from MBR systems, the sequential reduction of the largest fractions leading to an

531 accumulation of some of the lightest components, namely BB and LMWA, could be

532 clearly observed. Also for these waters, a net level of OM mineralization took place. In

533 general, an accumulation of low molecular weight acids at the end of the treatment was

534 registered. Correlations between some observed changes (variation in humic substances

535 concentration), water quality $\left(\mathrm{UVA}_{254}\right)$ and process parameters $\left(\mathrm{IOD}, \int[\cdot[\mathrm{OH}] \mathrm{d} t / \mathrm{IOD}\right.$,

536 TOD) were established. Changes in organic matter concentration and characteristics

537 derived from ozone application could be detrimental for water reuse purposes, depending

538 on the final application of the treated water. Thus, accumulation of lower weight fractions

539 could lead to bacterial growth or eutrophication, and the increase in humic substances

540 concentration upon oxidation of particular/colloidal matter is in any case detrimental

541 because of the general increase in the DOC content. Thus, a careful consideration of this

542 factor together with the water properties of the effluent to treat and the quality 
543 requirements to achieve throughout the process (e.g., micropollutants removal) should be

544 properly assessed during the planning stage of an ozonation unit.

545

\section{Acknowledgements}

547

548 This work was financially supported by the Spanish Ministry of Economy and

549 Competitiveness (project CTQ2017-86466-R and Alberto Cruz's FPI fellowship BES-

550 2015-074109) and the Agency for Management of University and Research Grants of the

551 Government of Catalonia (project 2017SGR131).

552

553 References

554

555

556

[1]D. Fatta-Kassinos, D.D. Dionysiou, K. Kümmerer, Wastewater reuse and current challenges, Springer, 2016.

[2]W.W.A. Programme, The United Nations world water development report 2015: Water for a sustainable world, Paris, 2015.

559

560

[3]D. Bixio, C. Thoeye, J. De Koning, D. Joksimovic, D. Savic, T. Wintgens, T. Melin,

560
Wastewater reuse in Europe, Desalination. 187 (2006) 89-101. doi:10.1016/J.DESAL.2005.04.070.

[4]M. Petala, V. Tsiridis, P. Samaras, A. Zouboulis, G.P. Sakellaropoulos, Wastewater reclamation by advanced treatment of secondary effluents, Desalination. 195 (2006) 109-118. doi:10.1016/J.DESAL.2005.10.037.

565 [5]J. Gomes, R. Costa, R.M. Quinta-Ferreira, R.C. Martins, Application of ozonation for pharmaceuticals and personal care products removal from water, Sci. Total Environ. 586 (2017) 265-283. doi:10.1016/j.scitotenv.2017.01.216. 
[6]J. Reungoat, B.I. Escher, M. Macova, F.X. Argaud, W. Gernjak, J. Keller, Ozonation and biological activated carbon filtration of wastewater treatment plant effluents, Water Res. 46 (2012) 863-872. doi:10.1016/j.watres.2011.11.064.

[7]N. Nakada, H. Shinohara, A. Murata, K. Kiri, S. Managaki, N. Sato, H. Takada, Removal of selected pharmaceuticals and personal care products (PPCPs) and endocrine-disrupting chemicals (EDCs) during sand filtration and ozonation at a municipal sewage treatment plant, Water Res. 41 (2007) 4373-4382. doi:10.1016/j.watres.2007.06.038.

[8]D. Gerrity, S. Gamage, J.C. Holady, D.B. Mawhinney, O. Quiñones, R.A. Trenholm, S.A. Snyder, Pilot-scale evaluation of ozone and biological activated carbon for trace organic contaminant mitigation and disinfection, Water Res. 45 (2011) 21552165. doi:10.1016/j.watres.2010.12.031.

[9]S.G. Zimmermann, M. Wittenwiler, J. Hollender, M. Krauss, C. Ort, H. Siegrist, U. von Gunten, Kinetic assessment and modeling of an ozonation step for full-scale municipal wastewater treatment: Micropollutant oxidation, by-product formation and disinfection, Water Res. $45 \quad$ (2011) 605-617. doi:10.1016/j.watres.2010.07.080.

[10] Y. Lee, D. Gerrity, M. Lee, A.E. Bogeat, E. Salhi, S. Gamage, R.A. Trenholm, E.C. Wert, S.A. Snyder, U. von Gunten, Prediction of micropollutant elimination during ozonation of municipal wastewater effluents: Use of kinetic and water specific information, Environ. Sci. Technol. 47 (2013) 5872-5881. doi:10.1021/es400781r.

[11] L. Rizzo, S. Malato, D. Antakyali, V.G. Beretsou, B.Đ. Maja, W. Gernjak, E. Heath, I. Ivancev-tumbas, P. Karaolia, A.R. Lado, G. Mascolo, C.S. Mcardell, H. Schaar, A.M.T. Silva, D. Fatta-kassinos, Consolidated vs new advanced treatment 
methods for the removal of contaminants of emerging concern from urban wastewater, Sci. Total Environ. $655 \quad$ (2019) 986-1008. doi:10.1016/j.scitotenv.2018.11.265.

[12] W. Yao, S. Waqi, U. Rehman, H. Wang, H. Yang, G. Yu, Y. Wang, Pilot-scale evaluation of micropollutant abatements by conventional ozonation, UV/O3, and an electro-peroxone process, Water Res. 138 (2018) 106-117. doi:10.1016/j.watres.2018.03.044.

600

[13] Y. Sun, B. Angelotti, M. Brooks, B. Dowbiggin, P.J. Evans, B. Devins, Z. Wang, 601 A pilot-scale investigation of disinfection by-product precursors and trace organic removal mechanisms in ozone-biologically activated carbon treatment for potable

reuse, Chemosphere.

210

(2018)

$539-549$. doi:10.1016/j.chemosphere.2018.06.162. 606

[14] M. Bourgin, B. Beck, M. Boehler, E. Borowska, J. Fleiner, E. Salhi, R. Teichler, U. von Gunten, H. Siegrist, C.S. McArdell, Evaluation of a full-scale wastewater treatment plant upgraded with ozonation and biological post-treatments: Abatement of micropollutants, formation of transformation products and oxidation by-products, Water $\quad$ Res. 129 (2018) 486-498.

611 [15] S. Tripathi, V. Pathak, D.M. Tripathi, B.D. Tripathi, Application of ozone based treatments of secondary effluents, Bioresour. Technol. 102 (2011) 2481-2486. doi:10.1016/j.biortech.2010.11.028.

614 [16] J. Rivas, O. Gimeno, F. Beltrán, Wastewater recycling: Application of ozone 615 based treatments to secondary effluents, Chemosphere. 74 (2009) 854-859. doi:10.1016/j.chemosphere.2008.07.090.

617 [17] R. Rosal, A. Rodríguez, J.A. Perdigón-melón, A. Petre, E. García-calvo, Oxidation 
of dissolved organic matter in the effluent of a sewage treatment plant using ozone combined with hydrogen peroxide (O3/H2O2), Chem. Eng. J. 149 (2009) 311318. doi:10.1016/j.cej.2008.11.019.

[18] B. Domenjoud, C. Tatari, S. Esplugas, S. Baig, Ozone-based processes applied to municipal secondary effluents, Ozone Sci. Eng. 33 (2011) 243-249. doi:10.1080/01919512.2011.571166.

[19] A. Papageorgiou, S.K. Stylianou, P. Kaffes, A.I. Zouboulis, D. Voutsa, Effects of ozonation pretreatment on natural organic matter and wastewater derived organic matter e Possible implications on the formation of ozonation by-products, Chemosphere. 170 (2017) 33-40. doi:10.1016/j.chemosphere.2016.12.005.

[20] M. Marce, B. Domenjoud, S. Esplugas, S. Baig, Ozonation treatment of urban primary and biotreated wastewaters: Impacts and modeling, Chem. Eng. J. 283 (2016) 768-777. doi:10.1016/j.cej.2015.07.073.

[21] S.A. Huber, A. Balz, M. Abert, W. Pronk, Characterisation of aquatic humic and non-humic matter with size-exclusion chromatography - organic carbon detection - organic nitrogen detection (LC-OCD-OND), Water Res. 45 (2011) 879-885. doi:10.1016/j.watres.2010.09.023.

[22] J. Gong, Y. Liu, X. Sun, O3 and UV/O3 oxidation of organic constituents of biotreated municipal wastewater, Water Res. 42 (2008) 1238-1244. doi:10.1016/j.watres.2007.09.020.

[23] C. Liu, P. Li, X. Tang, G. V Korshin, Ozonation effects on emerging micropollutants and effluent organic matter in wastewater : characterization using changes of three-dimensional HP-SEC and EEM fluorescence data, Environ. Sci. Pollut. Res. 23 (2016) 20567-20579. doi:10.1007/s11356-016-7287-8.
O. González,
A. Justo, J. Bacardit, E.
E. Ferrero, J.J. Malfeito,
C. Sans, 
Characterization and fate of effluent organic matter treated with $\mathrm{UV} / \mathrm{H} 2 \mathrm{O} 2$ and ozonation, Chem. Eng. J. 226 (2013) 402-408. doi:10.1016/j.cej.2013.04.066.

[25] C. Liu, V. Nanaboina, G. Korshin, Spectroscopic study of the degradation of 646 antibiotics and the generation of representative EfOM oxidation products in ozonated wastewater, Chemosphere. $86 \quad$ (2012) 774-782. doi:10.1016/j.chemosphere.2011.11.003.

[26] F.L. Rosario-ortiz, S.P. Mezyk, E.C. Wert, D.F.R. Doud, M.K. Singh, M. Xin, S. Baik, S.A. Snyder, Effect of ozone oxidation on the molecular and kinetic doi:10.1016/j.watres.2012.07.034.

666

[31] W. Qi, H. Zhang, C. Hu, H. Liu, J. Qu, Effect of ozonation on the characteristics 667 of ef fl uent organic matter fractions and subsequent associations with disinfection 
by-products formation, Sci. Total Environ. 610-611 (2018) 1057-1064. doi:10.1016/j.scitotenv.2017.08.194.

670

671

672

673

674

675

676

677

678

679

680

681

682

683

684

685

686

687

688

689

690

691

692

[32] H.K. Shon, S. Vigneswaran, S.A. Snyder, Effluent Organic Matter ( EfOM ) in Wastewater: Constituents, effects and treatment, Crit. Rev. Environ. Sci. Technol. 36 (2006) 327-374. doi:10.1080/10643380600580011.

[33] I. Michael-kordatou, C. Michael, X. Duan, X. He, D.D. Dionysiou, M.A. Mills, D. Fatta-Kassinos, Dissolved effluent organic matter: Characteristics and potential implications in wastewater treatment and reuse applications, Water Res. 77 (2015) 213-248. doi:10.1016/j.watres.2015.03.011.

[34] A. Cruz-Alcalde, S. Esplugas, C. Sans, Abatement of ozone-recalcitrant micropollutants during municipal wastewater ozonation: kinetic modelling and surrogate-based control strategies, Chem. Eng. J. 15 (2019) 1092-1100. doi:10.1016/j.cej.2018.10.206.

[35] A. Cruz-Alcalde, C. Sans, S. Esplugas, Priority pesticides abatement by advanced water technologies: The case of acetamiprid removal by ozonation, Sci. Total Environ. 599-600 (2017) 1454-1461. doi:10.1016/j.scitotenv.2017.05.065.

[36] Standard methods for the examination of water and wastewater, 21st ed., American Public Health Association/American Water Works Association/Water Pollution Control Federation, Washinghton, D.C. (USA), 2005.

[37] Organic carbon detector - DOC-Labor Dr. Huber, (2017). http://doc-labor.de (accessed January 27, 2019).

[38] M. Roustan, H. Debellefontaine, Z. Do-Quang, J.-P. Duguet, Development of a method for the determination of ozone demand of a water, Ozone Sci. Eng. 20 (1998) 513-520. doi:10.1080/01919519809480338.

[39] C. von Sonntag, U. von Gunten, Chemistry of ozone in water and wastewater 
treatment: From basic principles to applications, IWA Publishing, 2012.

694 [40] G. V Buxton, C.L. Greenstock, W.P. Helman, A.B. Ross, Critical review of rate constants for reactions of hydrated electrons, hydrogen atoms and hydroxyl radicals in aqueous solution, J. Phys. Chem. Ref. Data. 17 (1988) 513. doi:10.1063/1.555805.

[41] FOEN (Federal Office for the Environment), Qualité de l'eau: révision de l'ordonnance sur la protection des eaux, (2015). https://www.bafu.admin.ch/bafu/fr/home/themes/formation/communiques.msgid-59323.html (accessed January 7, 2019).

702

703

704

705

706

707

708

709

710

711

712

713

714

715

716

717

[42] L. Meunier, S. Canonica, U. von Gunten, Implications of sequential use of UV and ozone for drinking water quality, Water Res. 40 (2006) 1864-1876. doi:10.1016/j.watres.2006.02.030.

[43] Y. Schindler Wildhaber, H. Mestankova, M. Schärer, K. Schirmer, E. Salhi, U. von Gunten, Novel test procedure to evaluate the treatability of wastewater with ozone, Water Res. 75 (2015) 324-335. doi:10.1016/j.watres.2015.02.030.

[44] M. Marce, O. Palacios, A. Bartolomé, J. Caixach, S. Baig, S. Esplugas, Application of ozone on activated sludge: micropollutant removal and sludge quality, Ozone Sci. Eng. 39 (2017) 319-332. doi:10.1080/01919512.2017.1334535.

[45] B. Domenjoud, N. Cortés-Francisco, A.R. Guastalli, J. Caixach, S. Esplugas, S. Baig, Ozonation of municipal secondary effluent; Removal of hazardous micropollutants and related changes of organic matter composition, J. Adv. Oxid. Technol. 14 (2011) 138-146. doi:10.1515/jaots-2011-0117.

[46] X.M. Wang, X.Y. Li, Accumulation of biopolymer clusters in a submerged membrane bioreactor and its effect on membrane fouling, Water Res. 42 (2008) 855-862. doi:10.1016/j.watres.2007.08.031. 
718 [47] F.J. Beltran, Ozone reaction kinetics for water and wastewater systems, Lewis Publishers, Boca Raton, Florida (USA), 2003.

[48] P. Xu, M.L. Janex, P. Savoye, A. Cockx, V. Lazarova, Wastewater disinfection by ozone: Main parameters for process design, Water Res. 36 (2002) 1043-1055. doi:10.1016/S0043-1354(01)00298-6.

[49] Z. Chen, T. Yu, H.H. Ngo, Y. Lu, G. Li, Q. Wu, K. Li, Y. Bai, S. Liu, H.Y. Hu, Assimilable organic carbon (AOC) variation in reclaimed water: Insight on biological stability evaluation and control for sustainable water reuse, Bioresour. Technol. 254 (2018) 290-299. doi:10.1016/j.biortech.2018.01.111.

[50] T. Janhom, S. Wattanachira, P. Pavasant, Characterization of brewery wastewater with spectrofluorometry analysis, J. Environ. Manage. 90 (2009) 1184-1190. doi:10.1016/j.jenvman.2008.05.008.

[51] J. Tian, M. Ernst, F. Cui, M. Jekel, Correlations of relevant membrane foulants with UF membrane fouling in different waters, Water Res. 47 (2012) 1218-1228. doi:10.1016/j.watres.2012.11.043.

[52] H. Wang, Y. Wang, X. Li, Y. Sun, H. Wu, D. Chen, Removal of humic substances from reverse osmosis ( $\mathrm{RO}$ ) and nanofiltration ( NF ) concentrated leachate using continuously ozone generation-reaction treatment equipment, Waste Manag. 56 (2016) 271-279. doi:10.1016/j.wasman.2016.07.040. polymeric substances in biofilms under long-term exposure to ciprofloxacin antibiotic using fluorescence excitation-emission matrix and parallel factor analysis, Environ. Sci. Pollut. Res. 24 (2017) 13536-13545. doi:10.1007/s11356017-8986-5.

742 [54] R. H. S. Jansen, A. Zwijnenburg, A. W. G. J. van der Meer, M. Wessling, Outside- 
in trimming of humic substances during ozonation in a membrane contactor, Environ. Sci. Technol. 40 (2006) 6460-6465. doi:10.1021/ES060533T.

[55] R.D.V. and, N. V. Blough, On the origin of the optical properties of humic substances, Environ. Sci. Technol. $38 \quad$ (2004) 3885-3891. doi:10.1021/ES049912H.

[56] G. V. Korshin, C.-W. Li, M.M. Benjamin, Monitoring the properties of natural organic matter through UV spectroscopy: A consistent theory, Water Res. 31 (1997) 1787-1795. doi:10.1016/S0043-1354(97)00006-7.

[57] W.T. Li, M.J. Cao, T. Young, B. Ruffino, M. Dodd, A.M. Li, G. Korshin, Application of UV absorbance and fluorescence indicators to assess the formation of biodegradable dissolved organic carbon and bromate during ozonation, Water Res. 111 (2017) 154-162. doi:10.1016/j.watres.2017.01.009. 